\title{
Analisis Pengaruh Tingkat Pendidikan, Keterampilan, Upah Dan Umur Terhadap Lama Mencari Kerja Pada Tenaga Kerja Terdidik Di Kabupaten Manokwari
}

\author{
Makaria Mayoni, Yuyun P. Rahayu ${ }^{1}$, Marcus R. Maspaitella ${ }^{1}$ \\ ${ }^{1}$ Program Studi Ekonomi Pembangunan, Universitas Papua
}

\begin{abstract}
Abstrak
Penelitian ini bertujuan untuk mencari variabel yang paling mempengaruhi lama memperoleh kerja seorangg tenaga kerja terdidik untuk memperoleh pekerjaan. Beberapa faktor yang mempengaruhi berdasarkan penelitian terdahulu dan yang digunakan sebagai variabel independen antara lain: tingkat pendidikan, keterampilan, upah dan usia. Hipotesis yang akan dibuktikan adalah bahwa secara simultan dan parsial, keempat variabel mempengaruhi lama mencari kerja. Dengan menggunakan 100 orang responden tenaga kerja terdidik di Kabpaten Manokwari, analisis regresi dilakukan untuk membuktikan kebenaran hipotesis penelittian untuk area Kabupaten Manokwari. Hasilnya menunjukkan bahwa secara simultan, pada taraf kepercayaan 90\%, seluruh variabel independen mempengaruhi lama mencari kerja tenaga terdidik. Sedangkan, secara parsial, hanya variabel keterampilan yang berpengaruh secara signifikan terhadap lama mencari kerja.
\end{abstract}

Kata kunci: tenaga kerja, pendidikan, keterampilan, upah

\section{Abstract}

This study aims to find the variables that most influence the length of time to get a proper job for an educated workforce. Some influencing factors based on previous research which are used as independent variables include the level of education, skills, wages and age. This research hypothesises is that simultaneously and partially, the four variables affect the length of time seeking for a job. A regression analysis had been conducted to prove this hypothesis. This research used 100 educated labour as respondents in Manokwari Regency. The result shows that simultaneously, at a 90\% confidence level, all independent variables influence the length of time looking for a job. Meanwhile, partially, only the skill variable significantly influences it.

Keywords: labor, education, skills, wages

How to Cite: Mayoni, dkk. (2020). Analisis Pengaruh Tingkat Pendidikan, Keterampilan, Upah Dan Umur Terhadap Lama Mencari Kerja Pada Tenaga Kerja Terdidik Di Kabupaten Manokwari. JFRES: Journal of Fiscal and Regional Economy Studies, 3(1), 1 - 9 


\section{PENDAHULUAN}

Kecenderungan meningkatnya angka pengangguran tenaga kerja terdidik, kemungkinan disebabkan semakin tinggi pendidikan yang ditamatkan maka semakin tinggi pula untuk mendapatkan kesempatan kerja yang lebih sesuai, dan mereka lebih memilih pekerjaan yang diminati dan menolak pekerjaan yang tidak sesuai (Moelyono, 1997). Oleh karena itu, tenaga kerja terdidik lebih memilih pekerjaan sesuai dengan yang diminati tetapi ada juga tenaga kerja terdidik lebih memilih untuk menganggur dari pada harus cepat mendapatkan pekerjaan setelah selesai menempuh pendidikan dimana pekerjaan yang dikerjakan tidak sesuai dengan yang diminati.

Banyaknya jumlah tenaga kerja akan dapat memaksimalkan produktivitas kerja. Hal ini berdampak positif terhadap produktivitas tenaga kerja dimana dapat diartikan bahwa terjadi peningkatan kualitas dan kuantitas. Untuk mencapai peningkatan produktivitas, diperlukan keterampilan teknis, sehingga diharapkan akan mempunyai hasil guna yang tinggi, atau hasil output yang diperoleh seimbang dengan masukan (input ekonomi) yang diolah (Sinungan, 2005). Pengalaman kerja juga mempengaruhi produktivitas dalam bekerja, dimana dengan tingkat pendidikan yang tinggi dan didukung adanya pengalaman kerja, maka tenaga kerja akan mempunyai lebih banyak kesempatan untuk mendapatkan pekerjaan. Dengan pengalaman kerja, pencari kerja lebih sanggup untuk mendapatkan pekerjaan yang sesuai dengan keahliannya.

Lapangan pekerjaan merupakan indikator keberhasilan dalam penyelenggaraan pendidikan. Pendidikan sebagai sarana untuk mendapatkan sumberdaya manusia yang berkualitas karena pendidikan dianggap mampu untuk menghasilkan tenaga kerja yang bermutu tinggi, mempunyai pola pikir dan cara bertindak yang baik (Suryadi, 1995). Pendidikan merupakan suatu sarana untuk menghasilkan sumber daya manusia yang berkualitas dan mampu dalam melakukan suatu perubahan besar karena pendidikan bisa menciptakan para tenaga kerja yang profesional dan berpengalaman untuk bekerja.

Penduduk Kabupaten Manokwari tahun 2015 berjumlah 160.295 jiwa. Di bandingkan dengan jumlah penduduk tahun 2014 penduduk Kabupaten Manokwari mengalami pertumbuhan sebesar 2.61 persen. Sementara itu, besarnya angka rasio jenis kelamin tahun 2015 penduduk laki - laki terhadap penduduk perempuan sebesar 1,13 .

Jumlah angkatan kerja Kabupaten Manokwari pada tahun 2015 sebanyak 73.524. Tingkat pengangguran Kabupaten Manokwari 6.58 persen. Sedangkan yang bukan angkatan kerja pada tahun yang sama sebesar 38.952 jiwa yang terdiri dari penduduk yang masih sekolah, mengurus rumah tangga, dan lainnya, sehingga tingkat partisipasi angkatan kerja Kabupaten Manokwari adalah 65.37 persen.

Tabel 1. Jumlah Pencari Kerja, Lowongan Kerja berdasarkan Tingkat Pendidikan (SD-Perguruan Tinggi) di Kabupaten Manokwari Tahun 2014 -2016

\begin{tabular}{|c|c|c|c|c|c|}
\hline \multirow{2}{*}{ Tahun } & \multicolumn{2}{|c|}{ Pencari Kerja } & \multicolumn{2}{|c|}{ Lowongan Kerja } & \multirow{2}{*}{ Rasio } \\
\hline & Jumlah (Orang) & $\%$ & Jumlah (Orang) & $\%$ & \\
\hline 2014 & $13,554.00$ & 94.71 & $1,068.00$ & 315.97 & $13: 1$ \\
\hline 2015 & $14,311.00$ & 105.58 & 338.00 & 31.64 & $42: 1$ \\
\hline 2016 & $* *$ & $* *$ & $* *$ & $* *$ & $* *$ \\
\hline
\end{tabular}

Keterangan : $* *=2016$ tidak tersedia karena tidak ada Sakernas Agustus 2016

Sumber: BPS Kabupaten Manokwari, 2016

Dari Tabel 1 dapat dilihat bahwa pencari kerja tingkat pendidikan SD-perguruan tinggi pada tahun 2014 jumlah rasio pencari kerja tingkat pendidikan lebih banyak yaitu, 13:1 sedangkan lowongan kerjanya terbatas. Pada tahun 2015, jumlah rasio tenaga kerja meningkat menjadi 42:1 dibanding tahun 2014, sedangkan jumlah lowongan kerja sangat terbatas.
Salah satu tujuan penting dalam penyediaan lapangan kerja yang cukup untuk pertumbuhan angkatan kerja, dimana pertumbuhan angkatan kerja lebih cepat dari pertumbuhan kesempatan kerja. Ada beberapa faktor yang menyebabkan terjadinya pertumbuhan angkatan kerja lebih cepat yaitu, pertumbuhan penduduk cenderung tinggi sehingga melebihi pertumbuhan angkatan 
kerja terhadap kesempatan kerja yang terbatas (Setiawan, 2010). Kesempatan kerja tidak terlepas dari faktor - faktor yang mempengaruhinya, seperti perkembangan jumlah penduduk dan angkatan kerja, tingkat produktivitas angkatan kerja.

Produktivitas merupakan faktor penting dalam mendorong kehidupan dan pertumbuhan ekonomi secara optimal. Produktivitas tenaga kerja merupakan bagian kewajiban tingkat hasil kerja yang harus diberikan pekerja kepada pemberi kerja. Untuk mencapai produktivitas tenaga kerja karyawan yang tinggi, perusahaan perlu memperhatikan masalah pendidikan, upah, insentif, usia dan pengalaman kerja dan merupakan faktor pendorong dalam dalam mencapai produktivitas kerja (Mahendra, 2014).

Tabel 2. Penduduk Usia Produktif 15 Tahun Ke Atas Menurut Jumlah Pencari Kerja, Jumlah Lowongan Kerja tahun 2014 - 2016

\begin{tabular}{rrrrrr}
\hline \multirow{2}{*}{ Tahun } & \multicolumn{2}{c}{ Pencari Kerja } & \multicolumn{2}{c}{ Lowongan Kerja } & \multirow{2}{*}{ Rasio } \\
\cline { 2 - 6 } & Jumlah (Orang) & \multicolumn{1}{c}{ \% } & Jumlah (Orang) & \multicolumn{1}{c}{$\%$} & \\
\hline 2014 & $104,829.00$ & 142.57 & 1.068 .00 & 315.97 & $98: 1$ \\
\hline 2015 & $73,524.00$ & 70.13 & 338.00 & 31.64 & $218: 1$ \\
\hline 2016 & $* *$ & $* *$ & $* *$ & $* *$ & $* *$ \\
\hline
\end{tabular}

Keterangan : $* *=2016$ tidak tersedia karena tidak ada Sakernas Agustus 2016

Sumber: BPS Kabupaten Manokwari 2016

Berdasarkan tabel 2 dapat dijelaskan bahwa pada tahun 2014 rasio angkatan kerja 98 banding 1, lebih sedikit dibandingkan dengan jumlah lowongan kerja. Sedangkan pada tahun 2015 jumlah pencari kerja lebih meningkat yaitu 218 banding 1, sehingga kesempatan untuk mendapatkan lowongan kerja lebih terbatas.

Permintaan tenaga kerja berkaitan dengan tenaga kerja yang dibutuhkan oleh suatu perusahaan atau instansi tertentu. Permintaan tenaga kerja biasa dipengaruhi oleh perubahan tingkat upah dan faktor-faktor lain yang mempengaruhi permintaan. Semakin tinggi upah atau gaji yang diberikan maka mengakibatkan semakin sedikit permintaan akan tenaga kerja (Setiawan, 2010). Faktor lain yang mempengaruhi adalah produktivitas, tingkat pendidikan dan pengalaman kerja.

Produktivitas tenaga kerja juga dapat mempengaruhi seseorang dalam memperoleh pekerjaan seperti pengalaman kerja. Dengan tingkat pendidikan yang tinggi dengan adanya pengalaman kerja, seorang pekerja akan mudah

\section{TINJAUAN PUSTAKA}

\section{Tenaga Kerja}

Tenaga kerja adalah penduduk usia kerja (15-64 tahun) atau jumlah penduduk dalam suatu negara yang dapat memproduksi barang dan jasa jika ada permintaan terhadap tenaga kerja (Aisya, untuk memiliki pekerjaan yang sesuai dengan pengalaman kerja dan keahlian pekerja tersebut dapat memaksimalkan pengetahuan dan skilnya (Mahendra, 2014).

Berdasarkan latar belakang, perlu dilakukan penelitian mengenai pengaruh tingkat pendidikan, keterampilan, upah dan umur terhadap lama mencari kerja bagi tenaga kerja terdidik. Pokok permasalahan dalam penelitian ini adalah adanya ketidakseimbangan antara jumlah angkatan kerja dengan kesempatan kerja yang terbatas, sehingga muncul masalah pengangguran tenaga kerja terdidik. Lamanya mencari kerja bagi tenaga kerja terdidik selain dipengaruhi oleh pendidikan dan pendapatan juga dipengaharui oleh faktor-faktor keterampilan, upah dan umur. Dengan demikian, tujuan dalam penelitian ini adalah untuk menganalisis pengaruh pendidikan, keterampilan, upah dan umur terhadap lama mencari kerja bagi tenaga kerja terdidik di Kabupaten Manokwari.

2006). Pada dasarnya tenaga kerja dapat dibagi menjadi dua kelompok yaitu :

1. Angkatan Kerja, yaitu tenaga kerja berusia 15 tahun ke atas dan yang bekerja selama seminggu yang lalu mempunyai pekerjaan, baik yang bekerja maupun yang sementara tidak bekerja dan mereka yang tidak mempunyai pekerjaan 
tetap atau sedang mencari pekerjaan dan mengharapkan untuk mendapat pekerjaan.

2. Bukan Angkatan Kerja, yaitu tenaga kerja yang berusia 15 tahun ke atas yang selama seminggu yang lalu hanya bersekolah, mengurus rumah tangga dan lain - lain atau penerimaan pendapatan dan tidak melakukan kegiatan yang dapat dikategorikan bekerja, sementara tidak bekerja atau mencari kerja.

Menurut Wardani (2009), tenaga kerja terdidik umumnya produktivitas kerjanya akan lebih tinggi dari tenaga kerja tidak terdidik. Produktivitas kerja pada dasarnya dilihat dalam tingkat upah, tiap lowongan pekerjaan pada umumnya dikaitkan dengan tingkat pendidikan. Penyediaan tenaga kerja terdidik harus melalui sistem sekolah yang memerlukan waktu lama. Oleh karena itu elastisitas penyediaan tenaga kerja terdidik biasanya lebih kecil dari pada penyediaan tenaga kerja tidak terdidik.

Pengangguran dapat terjadi karena adanya ketidak seimbangan di dalam pasar tenaga kerja. Hal ini mengindikasikan bahwa jumlah tenaga kerja yang ditawarkan melebihi jumlah tenaga kerja yang diminta atau penawaran tenaga kerja lebih besar dari pada permintaan tenaga kerjannya. Menurut Kaufman dan Hotchkiss (1999) pengangguran dalam suatu perekonomian disebabkan oleh tiga hal:

\section{Proses mencari kerja}

Angkatan kerja baru akan menimbulkan persaingan yang ketat pada proses mencari kerja. Dalam proses ini terdapat hambatan dalam mencari kerja yaitu disebabkan karena adanya para pekerja yang ingin pindah ke pekerjaan lain, tidak sempurnanya informasi yang diterima para pencari kerja mengenai lapangan kerja yang tersedia, serta informasi yang tidak sempurna pada besarnya tingkat upah yang layak mereka terima.

\section{Kekakuan upah}

Besarnya pengangguran yang terjadi dipengaruhi juga oleh upah yang tidak fleksibel dalam pasar tenaga kerja. Penurunan pada proses produksi dalam perekonomian akan mengakibatkan pergeseran atau penurunan pada permintaan tenaga kerja. Akibatnya akan terjadi penurunan besarnya upah yang diterapkan.

\section{Efisensi upah}

Besarnya pengangguran dipengaruhi oleh efisiensi. Efisiensi yang terjadi pada fungsi tingkat upah tersebut terjadi karena semakin tinggi perusahaan membayar upah maka akan semakin keras usaha para pekerja untuk bekerja.

Hal ini justru memberikan konsekuensi yang buruk jika perusahaan memilih membayar lebih pada tenaga kerja yang memiliki efisiensi lebih tinggi maka akan terjadi pengangguran akibat dari persaingan yang ketat dalam mendapatkan pekerjaan yang diinginkan.

\section{Upah}

Upah merupakan imbalan finansial langsung yang dibayarkan kepada karyawan berdasarkan jam kerja, jumlah barang yang dihasilkan atau banyaknya pelayanan yang diberikan. Jadi tidak seperti gaji yang jumlahnya relatif tetap.

\section{METODE PENELITIAN}

Populasi adalah wilayah generalisasi yang terdiri atas subjek yang mempunyai karakteristik tertentu yang ditetapkan oleh peneliti untuk dipelajari dan kemudian ditarik kesimpulan (Sugiono, 2012). Jumlah populasi berasal dari jumlah pencari kerja menurut tingkat pendidikan yang terdaftar pada tahun 2015 sebesar 14.311 (tabel 1). Dari jumlah tersebut, diambil sebanyak 13.816 atau 96.54 persen jumlah pencari kerja dengan tingkat pendidikan minimal SMA dan Perguruan tinggi yang menjadi populasi dan sampel dalam penelitian ini.

Teknik pengambilan sampel mengunakan metode purposive sampling, teknik ini merupakan penentuan sampel dengan pertimbangan khusus sehingga layak dijadikan sampel (Sanusi, 2011). Dalam penelitian ini yang menjadi pertimbangan khusus adalah jumlah pencari kerja dengan tingkat pendidikan minimal SMA dan perguruan tinggi yang dihitung mengunakan rumus Slovin diperoleh 100 orang responden.

Hubungan antara variabel dapat digambarkan sebagai berikut : 


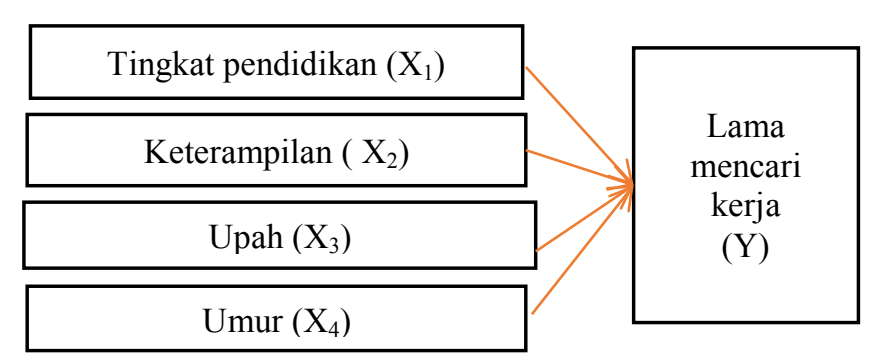

Gambar 1. Kerangka Hubungan Variabel

\section{Hipotesis}

Hipotesis adalah suatu jawaban sementara dan pedoman serta arah dalam penelitian yang disusun berdasarkan pada teori yang terkait, dimana suatu hipotesis selalu dirumuskan dalam bentuk pernyataan yang menghubungkan dua variabel atau lebih (Supranto, 1997). Adapun hipotesis yang diuji dalam penelitian ini :

$\mathrm{H}_{0}=$ diduga tingkat pendidikan, keterampilan, upah dan umur tidak berpengaruh terhadap lama mencari kerja, tenaga kerja terdidik di Kabupaten Manokwari.

$\mathrm{H}_{1}=$ diduga tingkat pendidikan, keterampilan, upah, dan umur berpengaruh terhadap lama mencari kerja, tenaga kerja terdidik di Kabupaten Manokwari.

Dalam menganalisis faktor-faktor apa saja yang mempengaruhi lama mencari kerja bagi tenaga kerja terdidik di Kabupaten Manokwari digunakan model sebagai berikut :

$Y=\beta_{0}+\beta_{1} X_{1}+\beta_{2} X_{2}+\beta_{3} X_{3}+\beta_{4} X_{4}+\mu$

Keterangan :

$\mathrm{Y}=$ Lama mencari kerja (bulan)

$\mathrm{X}_{1}=$ Tingkat pendidikan (skor)

$\mathrm{X}_{2}=$ keterampilan (skor)

$\mathrm{X}_{3}=$ Upah (Rupiah/bulan)

$\mathrm{X}_{4}=$ Umur (tahun)

$\mathrm{B}_{0}=$ Nilai Konstanta

$\beta_{1}, \beta_{2}, \beta_{3}, \beta_{4}=$ Koefisien regresi

$\mu=$ Variabel penganggu

\section{Definisi Operasional Variabel}

1. Lama mencari kerja (Y)
Lama mencari kerja merupakan waktu yang dilalui oleh pencari kerja untuk mendapatkan pekerjaan yang sekarang ditekuni sejak selesai menempuh pendidikan yang tinggi. Satuan yang digunakan untuk mengukur variabel lama mencari kerja adalah bulan.

\section{Tingkat pendidikan (X1)}

Tingkat pendidikan merupakan jenjang pendidikan yang ditempuh oleh responden dalam menyelesaikan pendidikan atau tahun sukses pendidikan, satuan yang digunakan untuk mengukur variabel tingkat pendidikan bersifat dummy, dimana skor 1 menyatakan untuk responden yang tingkat pendidikannya SMA dan skor 2 lainnya untuk responden yang menempuh jenjang pendidikan pada perguruan tinggi.

\section{Keterampilan (X2)}

Keterampilan menyatakan apakah responden memiliki suatu keteramapilan pada saat mendapatkan pekerjaan keterampilan tertentu pada saat memperoleh pekerjaan yang ditekuni saat ini. Satuan yang digunakan untuk mengukur variabel keterampilan bersifat dummy, dimana skor 1 menyatakan bahwa responden memiliki keterampilan dan skor 0 menyatakan sebaliknya.

\section{Upah (X3)}

Upah yang dimaksud dalam penelitian ini adalah jumlah seluruh penghasilan atau penerimaan yang diperoleh responden baik berupa gaji ataupun upah dari usaha dan pendapatan lainnya selama satu bulan. Variabel upah diukur dengan satuan Rupiah/bulan.

\section{Umur (X4)}

Umur menyatakan umur responden pada saat mendapatkan pekerjaan yang dijalani sekarang. Variabel umur diukur dalam satuan tahun. 


\section{HASIL DAN PEMBAHASAN}

\section{Karakterisitk Responden}

Jumlah sampel dalam penelitian ini berjumlah 100 responden: Karakteristik responden secara umum yang dibahas meliputi jenis kelamin, usia, tingkat pendidikan, asal daerah, dan status kependudukan. responden yang jenis kelamin laki-laki lebih banyak yaitu sebanyak 69 jiwa. Karena dimana tenega kerja atau karyawan, kelompok usia responden yang didominasi oleh kelompok reponden umur 23-47 sebesar 23 persen. Proporsi ini menunjukkan bahwa lebih banyak tenaga kerja atau karyawan muda yang dibutuhkan dan yang mempunyai skill. Dari kelompok usia tersebut, tenaga kerja atau karyawan tergolong dalam usia produktif.

Tenaga kerja atau karyawan yang status kependudukannya tinggal dan menetap di Kabupaten Manokwari sebanyak 84 jiwa atau 84 persen. Hampir sebagian besar tenaga kerja atau karyawan penduduk asli Manokwari berdasarkan KTP (Kartu Tanda Penduduk) yang diterbitkan pemerintah Kabupaten Manokwari. Sedangkan untuk tenaga kerja atau karyawan yang perantau sebesar 16 persen. Mereka adala para tenaga kerja atau karyawan yang berasal dari luar Manokwari (Perantauan).

Selanjutnya, rata-rata lama mencari kerja selama 37,6 dibulatkan menjadi 38 bulan dan standar deviasinya sebesar 15,2. Rata-rata variabel tingkat pendidikan sebesar 1.7 atau setara Sarjana strata 1 dan tingkat sebaran datanya sebesar 0.4. Rata-rata variabel keterampilan sebesar 0,8 atau 1 yang artinya memiliki keahlian dan tingkat sebaran datanya sebesar 0,4 . Rata-rata variabel upah sebesar 2,7 juta rupiah per bulan dan tingkat sebarannya 0,9 . Yang terakhir adalah rata-rata variabel umur sebesar 32,4 tahun dan tingkat sebsarannya 7,6. Dengan deskripsi ini diketahui seorang sarjana di Kabupaten Manokwari memerlukan waktu rata-rata selama 3 tahun 2 bulan setelah menyelesaikan pendidikannya (rata-rata sarjana) sebelum memperoleh pekerjaan tetap yang sesuai dengan upah yang diinginkan.

Tabel 3. Coeffcients

\begin{tabular}{|c|c|c|c|c|c|}
\hline \multirow[t]{2}{*}{ Model } & $\begin{array}{c}\text { Unstandardized } \\
\text { Coefficients }\end{array}$ & \multirow[t]{2}{*}{ Std. Error } & $\begin{array}{l}\text { Standardized } \\
\text { Coefficients }\end{array}$ & \multirow[t]{2}{*}{$\mathrm{t}$} & \multirow[t]{2}{*}{ Sig. } \\
\hline & B & & Beta & & \\
\hline (Costanta) & 37.808 & 9.748 & & 3.879 & 0.000 \\
\hline Tingkat Pendidikan & 1.439 & 3.562 & -0.040 & -0.404 & 0.687 \\
\hline Keterampilan & -9.492 & 3.814 & -0.246 & -2.489 & 0.015 \\
\hline Upah & 1.021 & 1.564 & 0.065 & 0.063 & 0.515 \\
\hline Umur & 0.221 & 0.197 & 0.112 & 1.121 & 0.265 \\
\hline
\end{tabular}

a. Dependent Variable: lama mencari kerja

Sumber : Data Primer diolah, 2018

\section{Hasil Analisis Regresi Linear}

Dari tabel 3 diperoleh hasil analisis regresi, apabila ditulis dalam bentuk persamaan regresi linear berganda adalah sebagai berikut :

Lama Mencari Kerja $=37.808+1.439 \mathrm{X}_{1}-$ $9.492 \mathrm{X}_{2}+1.021 \mathrm{X}_{3}+0.221 \mathrm{X}_{4}+\mathrm{e}$

Dari persamaan regresi linear pada Tabel 5.4 dapat diketahui, nilai koefisien sebesar 37.808 dan jika tingkat pendidikan $\left(\mathrm{X}_{1}\right)$, Keterampilan $\left(\mathrm{X}_{2}\right)$, upah $\left(\mathrm{X}_{3}\right)$, umur $\left(\mathrm{X}_{4}\right)$ nilainya adalah 0 , maka lama mencari kerja (Y) nilainya 37.808

Nilai signifikan dari variabel tingkat pendidikan adalah 0.687 dimana hasil tersebut lebih besar dari nilai signifikan 0.05 dan bertanda negatif, artinya bahwa variabel tingkat pendidikan berpengaruh negatif dan tidak signifikan terhadap variabel lama mencari kerja.

Nilai signifikan dari variabel keterampilan adalah 0.015 dimana hasil tersebut lebih kecil dari nilai signifikan 0.05 dan bertanda positif, artinya bahwa variabel pengalaman kerja berpengaruh posisitif dan signifikan terhadap variabel lama mencari kerja.

Nilai signifikan dari variabel upah adalah 0.515 dimana hasil tersebut lebih besar dari nilai signifikan 0.05 dan bertanda negatif, artinya bahwa variabel upah berpengaruh negatif dan 
tidak signifikan terhadap variabel lama mencari kerja.

Nilai signifikan dari variabel umur adalah 0.265 dimana hasil tersebut lebih besar dari nilai signifikan 0.05 dan bertanda negatif, artinya bahwa variabel upah berpengaruh negatif dan tidak signifikan terhadap variabel lama mencari kerja.

Tabel 4. Uji Simultan (Uji F Statistik)

\section{Uji Statistik}

Uji pengaruh simultan digunakan untuk mengetahui apakah variabel independen (Tingkat pendidikan, keterampilan, Upah, dan Umur) secara bersama-sama atau simultan mempengaruhi variabel dependen (lama mencari kerja).

ANOVA $^{b}$

\begin{tabular}{lrrrrr}
\hline \multicolumn{1}{c}{ Model } & Sum of Squares & Df & Mean Square & F & \multicolumn{1}{l}{ Sig. } \\
\hline Regression & $1,921.818$ & 4 & 480.455 & 2.172 & $0.078^{\text {a }}$ \\
\hline Residual & $21,018.822$ & 95 & 221.251 & & \\
\hline Total & $22,940.640$ & 99 & & & \\
\hline
\end{tabular}

a. Predictors: (Constant), umur, keterampilan, Tingkatpendidikan, upah

b. Dependent Variable: lama mencari kerja

Sumber : Data Primer Diolah, 2018

Dari hasil uji F diperoleh nilai signifikan kurang dari nilai probabilitas 0,5 atau nilai $0,078>0,5$ atau dilihat oleh perbandingan nilai $\mathrm{F}$ hitung dengan $\mathrm{F}$ tabel. Nilai $\mathrm{F}$ tabel dengan tingkat kepercayaan 95 persen, adalah 1.592 (dapat dilihat pada lampiran). F hitung lebih kecil dari F tabel, maka $\mathrm{H}_{1}$ ditolak dan $\mathrm{H}_{0}$ diterima, berarti secara bersama-sama (simultan) variabel tingkat pendidikan, keterampilan, upah, dan umur mempengaruhi lama mencari kerja pada tingkat kepercayaan 95 persen. Namun dalam tingkat kepercayaan 90 persen atau probabilitas 0,10 variabel tingkat, pendidikan, keterampilan, upah, dan umur berpengaruh signifikan terhadap lama mencari kerja.

\section{Uji t}

Uji t digunakan untuk mengetahui apakah variabel-variabel independen secara parsial berpengaruh terhadap variabel dependen. Tingkat signifikan yang digunakan adalah 0,05 hasil uji t yang dilihat dari hasil regresi pada tabel 3 adalah sebagai berikut :

\section{Variabel tingkat pendidikan $\left(X_{I}\right)$ terhadap} lama mencari kerja (Y)

Dilihat dalam tabel 3 terdapat nilai signifikan 0,678. Nilai signifikan lebih kecil dari probabilitas 0,05 atau nilai $0,678>0,05$ maka $\mathrm{H}_{0}$ diterima dan $\mathrm{H}_{1}$ ditolak, artinya hipotesis menyatakan bahwa variabel tingkat pendidikan $\left(\mathrm{X}_{1}\right)$ tidak berpengaruh signifikan terhadap lama mencari kerja.

\section{Variabel keterampilan $\left(X_{2}\right)$ terhadap lama} mencari kerja $(Y)$

Dilihat dalam tabel 3 terdapat nilai signifikansi sebesar 0,015 . Nilai tersebut jika dibandingkan dengan probabilitas 0,05 hasilnya sangat signifikan. Maka $\mathrm{H}_{1}$ diterima dan $\mathrm{H}_{0}$ ditolak, artinya hipotesis yang menyatakan bahwa variabel keterampilan $\left(\mathrm{X}_{2}\right)$ berpengaruh signifikan terhadap lama mencari kerja (Y) dapat diterima.

\section{Variabel upah $\left(X_{3}\right)$ terhadap lama mencari} kerja $(Y)$

Dapat dilihat dalam tabel 3 nilai signifikansi 0,515 . Nilai signifikansi ini lebih besar dari probabilitas 0,05 atau nilai $0,515>0,5$. Maka $\mathrm{H}_{1}$ ditolak dan $\mathrm{H}_{0}$ diterima. Artinya, hipotesis yang menyatakan bahwa tidak ada pengaruh yang signifikan antara keterampilan tenaga kerja $\left(\mathrm{X}_{3}\right)$ secara parsial terhadap lama mencari kerja (Y) tidak dapat diterima

4. Variabel umur $\left(X_{4}\right)$ terhadap lama mencari $\operatorname{kerja}(Y)$ 
Dapat dilihat dalam tabel 3 terdapat nilai signifikansi 0,265 yang besar lebih besar dari nilai probabilitas 0,05 . Maka, $\mathrm{H}_{1}$ ditolak dan $\mathrm{H}_{0}$ diterima. Artinya, hipotesis menyatakan bahwa ada pengaruh yang signifikan antara tenaga kerja $\left(\mathrm{X}_{4}\right)$ terhadap lama mencari kerja. (Y) tidak diterima.

\section{Koefisien Determinasi (R2)}

Koefisien determinasi digunakan untuk menjelaskan seberapa besar pengaruh variabelvariabel bebas memiliki pengaruh terhadap variabel terikat. Nilai koefisien determinasi digunakan Adjusted $R$ Square. Dari hasil perhitungan dapat diketahui bahwa koefisien determinasi (Adjusted $R^{2}$ ) yang di peroleh sebesar 0,084. hal ini menunjukkan bahwa variabel tingkat pendidikan, keterampilan, upah dan umur menerangkan 8,4 persen variasi lama mencari kerja. Sedangkan sisahnya 92,6 persen dijelaskan oleh variabel lain yang tidak dimasukkan dalam model analisis dalam penelitian ini. Nilai $\mathrm{R}^{2}$ yang sangat kecil menunjukkan bahwa ada variabel lain selain keterampilan yang mampu menjelaskan variasi pada lama mencari kerja tenaga kerja terdidik di Kabupaten Manokwari.

\section{KESIMPULAN}

Dari analisis data yang telah dilakukan dapat diperoleh kesimpulan sebagai berikut :

1. Variabel tingkat pendidikan berpengaruh positif tetapi tidak signifikan terhadap lama mencari kerja. Berarti bahwa semakin tingginya tingkat pendidikan pencari kerja justru akan semakin lama waktu yang digunakan untuk mencari kerja.

2. Variabel keterampilan berpengaruh negatif tetapi signifikan terhadap lama mencari kerja. Berarti bahwa keterampilan yang dimiliki oleh pencari kerja akan lebih mudah untuk mempermudah pencari kerja untuk lebih cepat mendapatkan pekerjaannya.

3. Variabel upah berpengaruh positif tetapi tidak signifikan terhadap lama mencari kerja. Berarti bahwa semakin tinggi harapan upah yang akan diperoleh akan semakin lama waktu yang dibutuhkan sampai mendapatkan pekerjaan.

4. Variabel umur memiliki pengaruh positif tetapi tidak signifikan terhadap lama mencari kerja. Berapapun umur seorang pencari kerja tidak akan menjadi penyebab lamanya orang tersebut untuk memperoleh pekerjaannya.

5. Secara keseluruhan variabel-variabel independen dalam model yang dihasilkan belum mampu secara nyata menjelaskan variasi variabel dependen $\left(\mathrm{R}^{2}=8.4 \%\right)$. Untuk itu disarankan unttuk menemukan variabel yang paling mempengaruhi lama seorang tenaga kerja terdidik memperoleh pekerjaan.

\section{DAFTAR PUSTAKA}

Aisya. 2006. Disparitasm Konservasi dan Determinan Produktivitas Tenaga Kerja. http://media.peneliti.com>publications.

BPS Kabupaten Manokwari. 2014. Kabupaten Manokwari Dalam Angka Tahun 2014.

BPS Kabupaten Manokwari. 2015. Kabupaten Manokwari Dalam Angka tahun 2014.

BPS kabupaten manokwari. 2015. Tenaga Kerja Kabupaten Manokwari Tahun 2015.

Kaufman dan Hotchkiss. 1999 The Economic Labor markets. USA: Georgia State University.

Mahendra. 2014. "Analisis Pengaruh Pendidikan, Upah, Jenis Kelamin, Usia Pengalaman Kerja Terhadap Produktivitas Tenaga Kerja", dikota Semarang, Universitas Diponegoro.

Moelyono, 1997. Pengangguran tenaga kerja terdidik. Bumi Aksara, Jakarta.

Moelyono, Supriadi, 2006. Ekonomi sumber Daya Manusia. Jakarta: PT Raja Grafindo Persada.

Sanusi. Anwar 2011. Metode Penelitian, Jakarta.

Setiawan. 2010, “Analisis Penyerapan Tenaga Kerja Pada Sektor Usaha Kecil Dan Menegah (UKM) di Kota Semarang”.

Sinungan, Muchdarsyah 2005. Produktivitas: apa dan bagaimana. Edisi kedua. Bumi aksara. 
Sugiono, 2012. Metode Penelitian Kuantitatif Kualitaif dan R\&D Bandung: Alfabeta.

Supranto, J. 1997. Statistik teori dan Aplikasi. Jilid 1 Edisi ke Lima, Jakarta.

Wardani, Kusuma, Dewi. 2009. Riset Sumber Daya manusia, Jakarta: PT. Gramedia Pustaka Utama. 